\title{
Breaking the Selectivity-Conversion Limit of Partial Methane Oxidation with Tandem Heterogeneous Catalysts
}

Kimberly T. Dinh ${ }^{\dagger}$, Mark M. Sullivan ${ }^{\dagger}$, Pedro Serna ${ }^{ \pm}$, Randall J. Meyer ${ }^{ \pm}$, Yuriy Román-Leshkov ${ }^{\dagger \star}$

†Department of Chemical Engineering, Massachusetts Institute of Technology, 77 Massachusetts Avenue, Cambridge, Massachusetts 02139, United States

士ExxonMobil Research and Engineering, Annandale, New Jersey 08801, United States

*Corresponding author: yroman@mit.edu

\section{Table of Contents}

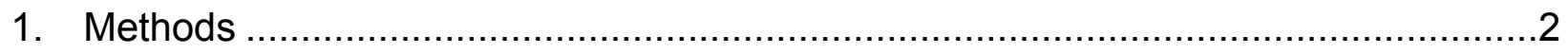

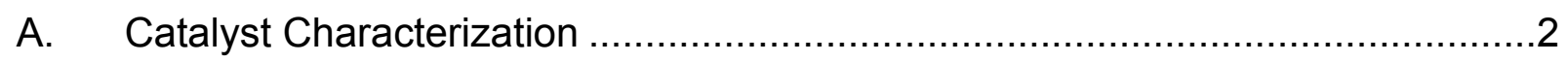

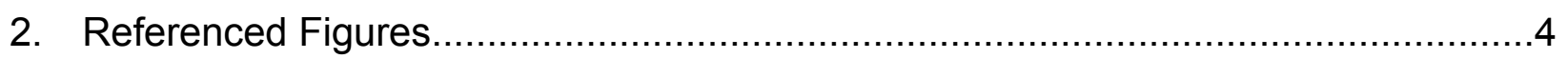

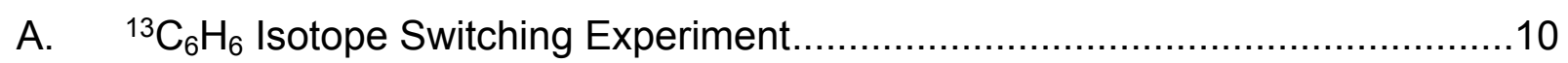

B. Estimation of Benzene Oxidation Across Conditions …...............................13

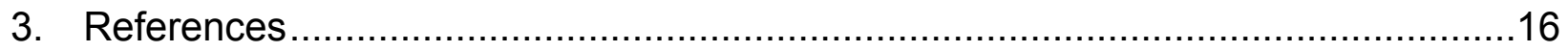




\section{Methods}

\section{A. Catalyst Characterization}

Elemental analysis

Copper, sodium and aluminum contents were determined using inductively coupled plasma atomic emission spectroscopy (ICP-AES, Agilent 5100) or inductively coupled plasma mass spectrometry (ICP-MS, Agilent 7900). $5-10 \mathrm{mg}$ of zeolite were placed in a polyethylene microfuge tube $(1.5 \mathrm{~mL}$ ) and digested in $20 \mu \mathrm{L}$ hydrofluoric acid (48 wt \%, trace metals basis, Sigma-Aldrich) for $2 \mathrm{~h}$. The hydrofluoric acid solution was diluted to a total mass of $10.0 \mathrm{~g}$ using 2 wt \% aqueous nitric acid $\left(\mathrm{HNO}_{3}\right)$ (veritas purity, GFS Chemicals). When using ICP-MS, $1 \mathrm{~mL}$ of these solutions were diluted once more to 10 $\mathrm{mL}$ solution total. A six point calibration curve was built using ICP standard solutions of $1,000 \mathrm{ppm} \mathrm{Cu}$ in $2 \mathrm{wt} \% \mathrm{HNO}_{3}, 1,000 \mathrm{ppm} \mathrm{Al}$ in $2 \mathrm{wt} \% \mathrm{HNO}_{3}$ and 1,000 ppm Na in $2 \mathrm{wt} \%$ $\mathrm{HNO}_{3}$. All standard solutions were purchased from Sigma-Aldrich (TraceCERT).

Calculations of molar ratios $\mathrm{Si} / \mathrm{Al}_{\text {tot }}$ and $\mathrm{Cu} / \mathrm{Al} \mathrm{Itot}_{\text {. }}$

The unit cell of a zeolite is given by:

$$
\mathrm{H}_{x}^{+} \mathrm{Na}_{y}^{+} \mathrm{Cu}_{z}^{2+}\left(\mathrm{AlO}_{2}\right)_{n}^{-}\left(\mathrm{SiO}_{2}\right)_{m}\left(\mathrm{H}_{2} \mathrm{O}\right)_{k}
$$

where subscripts refer to the molar ratios of each component within the unit cell of a zeolite. Local charge balance was assumed to occur within the zeolite, requiring $x=n-2 z-y$.

From the unit cell given above, the mass balance of the unit cell is given by the following equation on a per gram zeolite basis:

$$
1=a \frac{g \mathrm{SiO}_{2}}{\text { g zeolite }}+b \frac{g\left[\mathrm{AlO}_{2}\right]^{-}}{\text {g zeolite }}+c \frac{g \mathrm{Cu}^{2+}}{\text { g zeolite }}+d \frac{g \mathrm{Na}^{+}}{\text {g zeolite }}+e \frac{g \mathrm{H}^{+}}{g \text { zeolite }}+f \frac{g \mathrm{H}_{2} \mathrm{O}}{\text { g zeolite }}
$$

where each coefficient represents the weight percent of each species. The weight percent of $\mathrm{Al}, \mathrm{Cu}$ and $\mathrm{Na}$ were directly calculated using ICP-AES, allowing $b, c$, and $d$ to be determined. Converting the weight percentages of $\mathrm{Al}, \mathrm{Cu}$ and $\mathrm{Na}$ to mole percentages per gram zeolite, $e$ was then calculated using the local charge balance of cations on the zeolite framework. The weight percentage of $\mathrm{H}_{2} \mathrm{O}(f)$ was assumed to be equal to the weight percentage of $\mathrm{H}_{2} \mathrm{O}$ in the zeolite framework unit cell $(2-7 \mathrm{wt} \%) .{ }^{1}$ The mass balance was then solved for the weight percentage of $\mathrm{SiO}_{2}(a)$. 
$\mathrm{Si} / \mathrm{Al}_{\text {tot }}$ was calculated by $\frac{\mathrm{Si}}{\mathrm{Al} l_{\text {tot }}}=\frac{a m_{\mathrm{AlO} 2}}{b m_{\mathrm{SiO} 2}} \times \frac{1 \mathrm{~mol} \mathrm{Si}}{1 \mathrm{~mol} \mathrm{SiO}_{2}} \times \frac{1 \mathrm{~mol} \mathrm{AlO}}{2}$

where $m_{i}$ is the molar mass of element $i$.

$\mathrm{Cu} / \mathrm{Al}_{\text {tot }}$ was calculated by $\frac{\mathrm{Cu}}{\mathrm{Al} l_{\text {tot }}}=\frac{c m_{\mathrm{AlO2}}}{b \mathrm{~m}_{\mathrm{Cu}}} \times \frac{1 \mathrm{~mol} \mathrm{AlO}}{1 \mathrm{~mol} \mathrm{Al}}$

\section{Powder X-Ray Diffraction}

The crystal structures of zeolite catalysts were determined from powder $\mathrm{x}$-ray diffraction patterns collected using a Bruker D8 diffractometer using Cu-Ka radiation $(\lambda=1.5418 \AA$, $40 \mathrm{kV}, 40 \mathrm{~mA}$ ). Data were recorded in the range of 3-40 $2 \theta$ with an angular step size of $0.02^{\circ}$ and a rate of $4^{\circ} \mathrm{min}^{-1}$.

\section{Scanning Electron Microscopy}

Scanning electron microscopy was performed on a Zeiss Merlin High-resolution SEM. Samples were crushed into a fine powder and loaded on to carbon black tape. Micrographs were collected at $3.0 \mathrm{kV}, 100 \mathrm{pA}$, and $6.7 \mathrm{~mm}$ WD with the HE-SE2 detector in High Resolution column mode. 


\section{Referenced Figures}

A

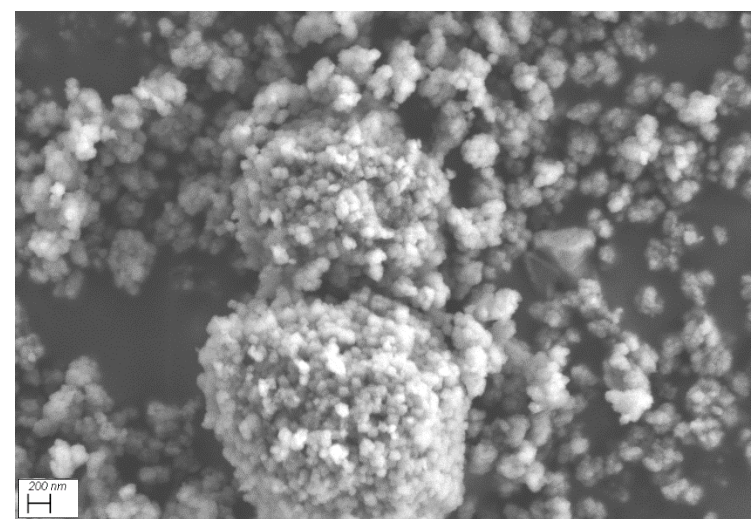

C

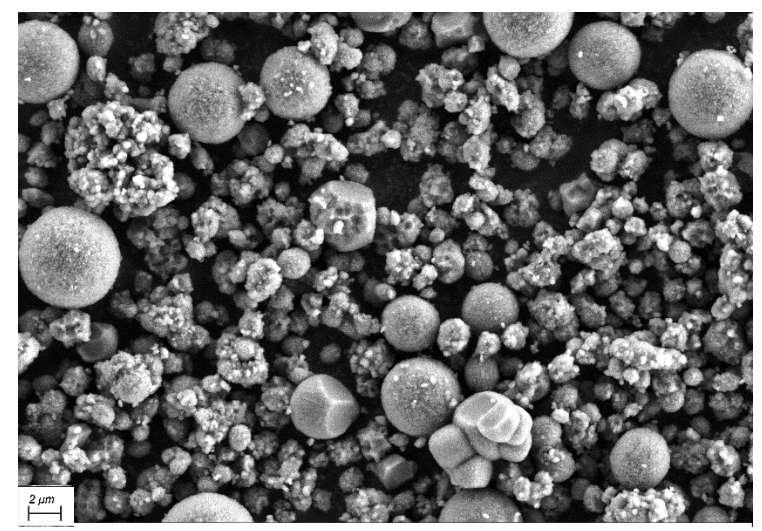

B

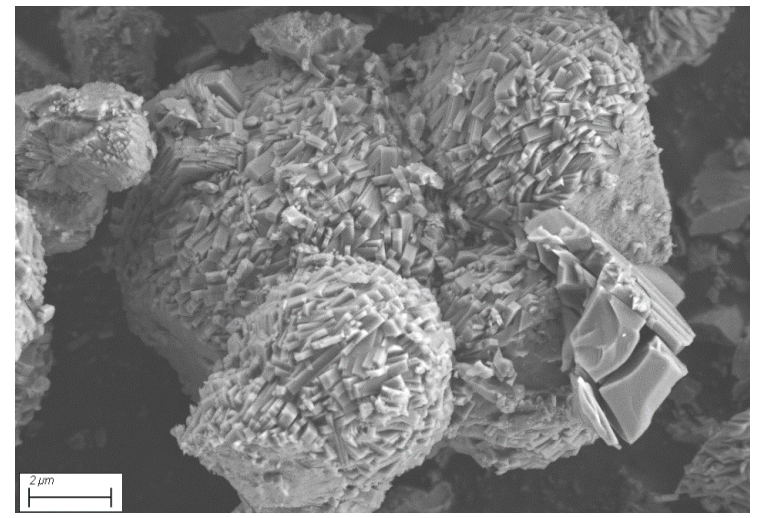

D

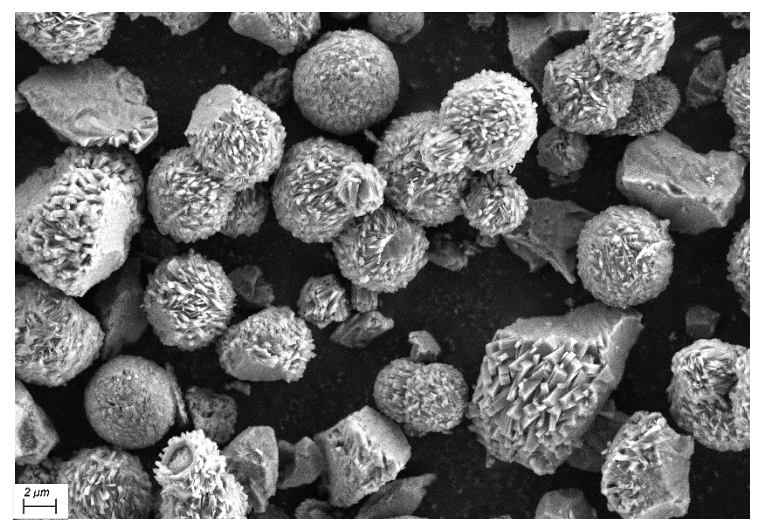

E

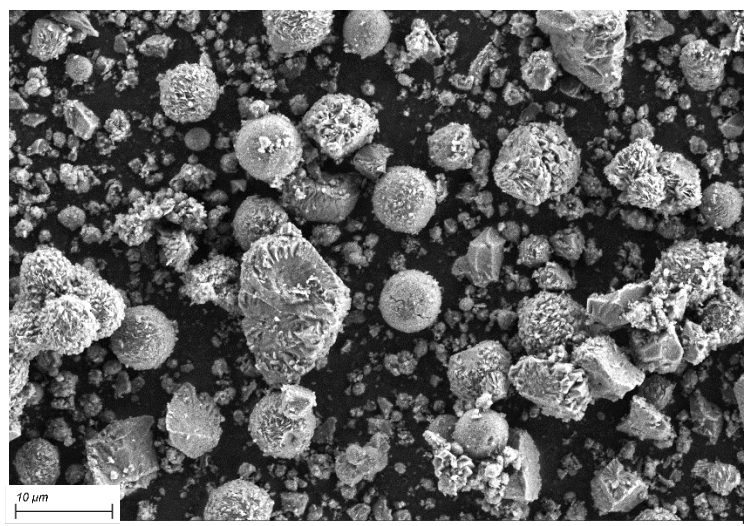

Figure S1. Representative SEM of A. Cu-SSZ-13-1, B. H-ZSM-5-1, C. Cu-SSZ-13-2, D. $\mathrm{H}-\mathrm{ZSM}-5-3$, and E. Cu-SSZ-13-2/H-ZSM-5-3 demonstrating differences in particle size distributions of the two zeolites and the predominance of large H-ZSM-5-3 particles in the mixture of Cu-SSZ-13-2/H-ZSM-5-3 
A

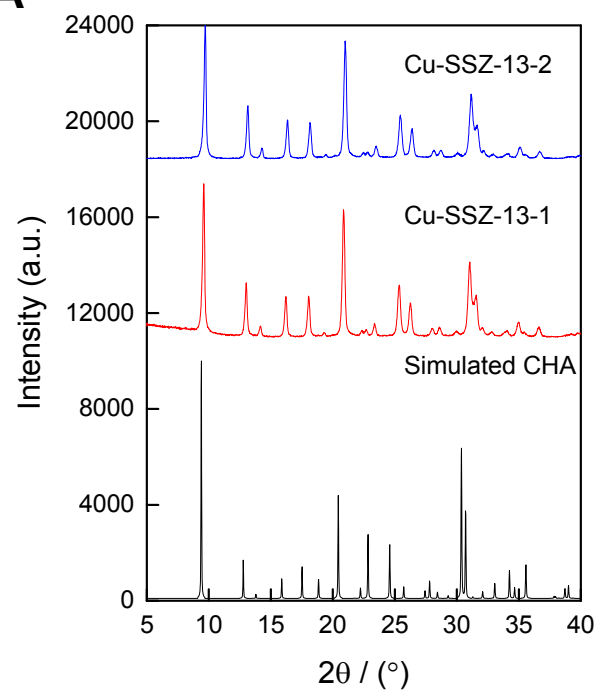

B

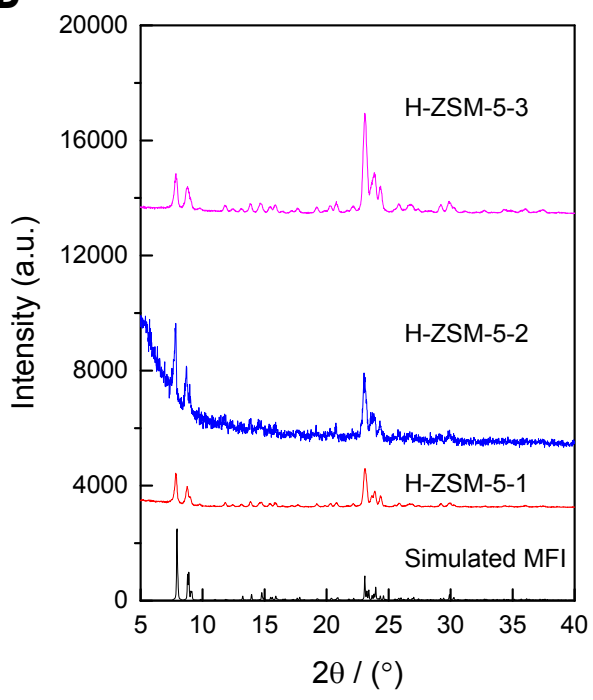

Figure S2. PXRD of A. Cu-SSZ-13 and B. H-ZSM-5. Simulated patterns were taken from the IZA Database of Zeolite Structures. ${ }^{1}$ PXRDs of Cu-SSZ-13 were taken following calcination to remove the OSDA and PXRD patterns were scaled to more clearly see all features.

Table S1. Catalyst composition of Cu-SSZ-13 and H-ZSM-5 used in this study

\begin{tabular}{|c|c|c|c|}
\hline \multirow{2}{*}{ Catalyst } & \multicolumn{2}{|c|}{ Composition } & \multirow{2}{*}{$\begin{array}{c}\mathrm{Cu} \\
\text { Content } \\
(w t \%)\end{array}$} \\
\hline & $\mathrm{Si} / \mathrm{Al}$ & $\mathrm{Cu} / \mathrm{Al}$ & \\
\hline Cu-SSZ-13-1 & 11 & 0.13 & 1.1 \\
\hline Cu-SSZ-13-2 & 13 & 0.13 & 0.9 \\
\hline H-ZSM-5-1 & 19 & - & - \\
\hline H-ZSM-5-2 & 16 & - & - \\
\hline H-ZSM-5-3 & 15 & - & - \\
\hline
\end{tabular}


Table S2. Parameters used for verification of absence of heat and mass transfer gradients. GradientCheck for Heterogeneous Catalysis was used. ${ }^{2}$ Gaseous properties were obtained from the NIST WebBook's Thermophysical Properties of Fluid Systems. ${ }^{3}$

\begin{tabular}{cc}
\hline $\begin{array}{c}\operatorname{max~r}_{\text {obs }} \\
\left(\mathrm{mol} \mathrm{kg}_{\left.\mathrm{cat}^{-1} \mathrm{~s}^{-1}\right)}\right.\end{array}$ & $1.30 \cdot 10^{-6}$ \\
$\begin{array}{c}\Delta \mathrm{H}_{\mathrm{rxn}} \\
\left(\mathrm{kJ} \mathrm{mol}^{-1}\right)\end{array}$ & -300 \\
$\mathrm{E}_{\mathrm{a}}$ & 100 \\
$\left(\mathrm{~kJ} \mathrm{~mol}^{-1}\right)$ & \\
$\begin{array}{c}\text { Fractional } \\
\text { conversion }\end{array}$ & 0.00004 \\
$\mathrm{n}$ & 1 \\
$\rho_{\text {bulk }}\left(\mathrm{kg} \mathrm{m}^{-3}\right)$ & 750 \\
$($ Assumed $\varepsilon=0.4)$ & \\
\hline
\end{tabular}




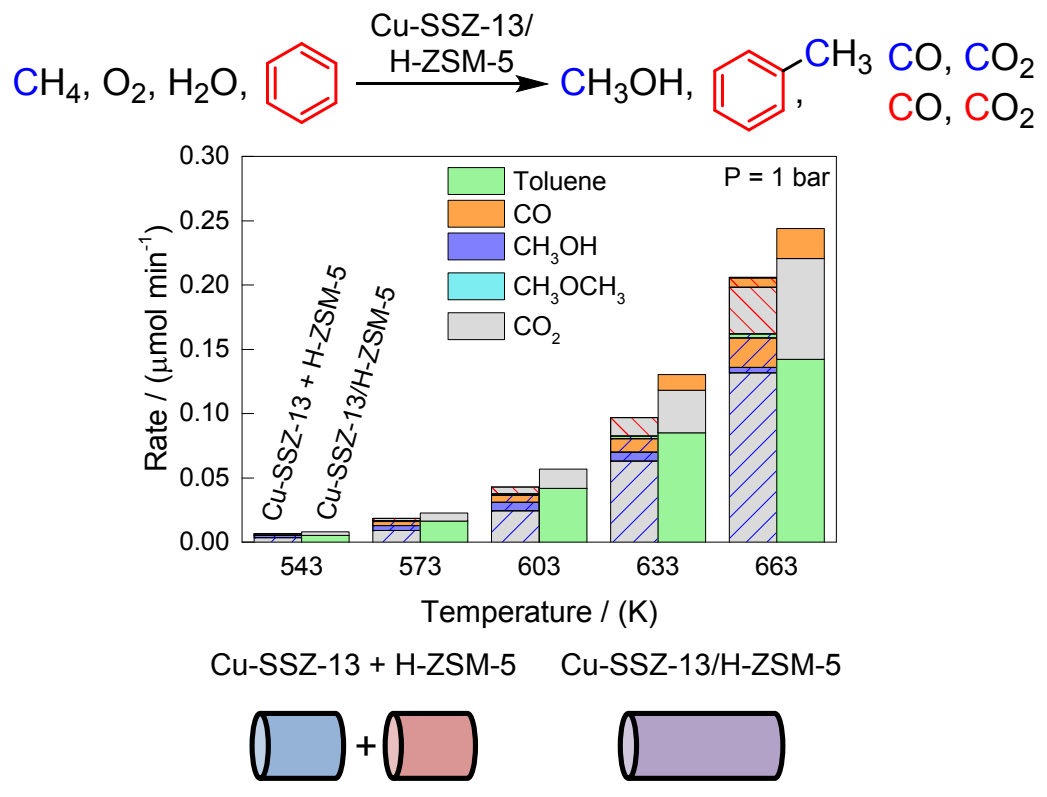

Figure S3. Comparison of product formation rates from separate catalysts beds of $\mathrm{Cu}$ SSZ-13 and H-ZSM-5 summed together (Cu-SSZ-13 + H-ZSM-5, where the results from individual beds of Cu-SSZ-13 and H-ZSM- 5 were added together to generate the left bars of the figure) to a single intimately mixed bed of Cu-SSZ-13 and H-ZSM-5 (Cu-SSZ-13/HZSM-5, right bars) when co-feeding a gas mixture of $\mathrm{CH}_{4} / \mathrm{O}_{2} / \mathrm{H}_{2} \mathrm{O} /$ benzene. Catalysts beds of Cu-SSZ-13, H-ZSM-5, and Cu-SSZ-13/H-ZSM-5 were tested under the same conditions. Bars with the blue diagonal lines are the rates observed over an individual bed Cu-SSZ-13 and the bars with the red diagonal lines are the rates observed over an individual bed of H-ZSM-5. Reaction conditions: $0.2625 \mathrm{~g} \mathrm{H}-\mathrm{ZSM}-5-1,0.0875 \mathrm{~g} \mathrm{Cu}-\mathrm{SSZ}-$ $13-1$, and $(0.0875 \mathrm{~g} \mathrm{Cu}-S S Z-13-1+0.2625 \mathrm{~g} \mathrm{H}-\mathrm{ZSM}-5-2), 26.1 \mathrm{sccm}, \mathrm{y}_{\mathrm{CH} 4}=0.18, \mathrm{y}_{\mathrm{C} 6 \mathrm{H} 6}$ $=0.008, \mathrm{y}_{\mathrm{O} 2}=0.001, \mathrm{P}_{\mathrm{H} 2 \mathrm{O}}=3.1 \mathrm{kPa}$, bal He .

Figure S3 demonstrates that across all temperatures, there is a slightly higher rate of product formation for the mixed bed of Cu-SSZ-13/H-ZSM-5 than from the addition of the rates of product formation over individual Cu-SSZ-13 and H-ZSM-5 beds. While the difference in total rates of formation is small at each temperature, higher total rates of product formation are observed across all temperatures with Cu-SSZ-13/H-ZSM-5. 


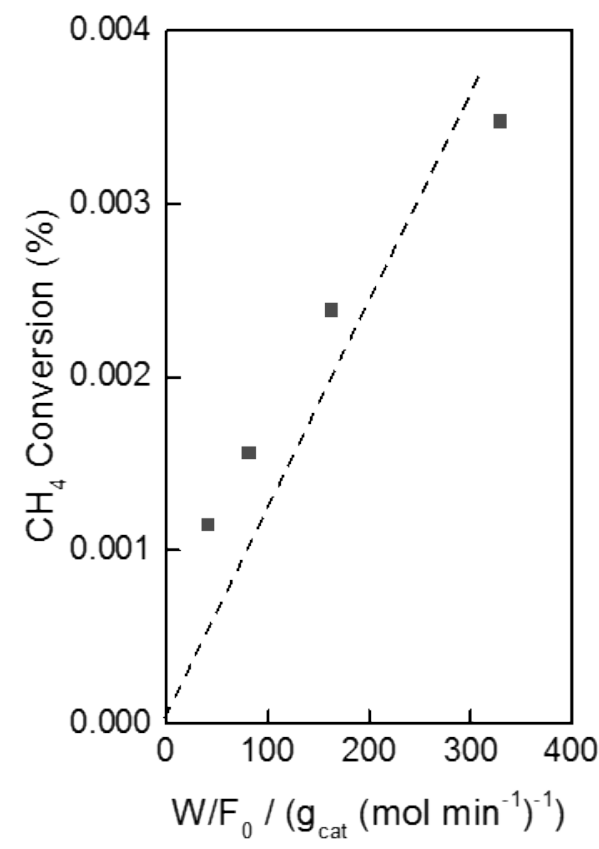

Figure S4. $\mathrm{CH}_{4}$ Conversion versus contact time for $(0.0875 \mathrm{~g} \mathrm{Cu}-\mathrm{SSZ}-13-1+0.2625 \mathrm{~g}$ $\mathrm{H}-\mathrm{ZSM}-5-2), 543 \mathrm{~K}, 1$ bar, $26.1-209 \mathrm{sccm}, \mathrm{P}_{\mathrm{CH} 4}=18 \mathrm{kPa}, \mathrm{P}_{\mathrm{O} 2}=0.09 \mathrm{kPa}, \mathrm{P}_{\mathrm{H} 2 \mathrm{O}}=3.1$ $\mathrm{kPa}, \mathrm{P}_{\mathrm{C} 6 \mathrm{H} 6}=0.80 \mathrm{kPa}$, bal He. 


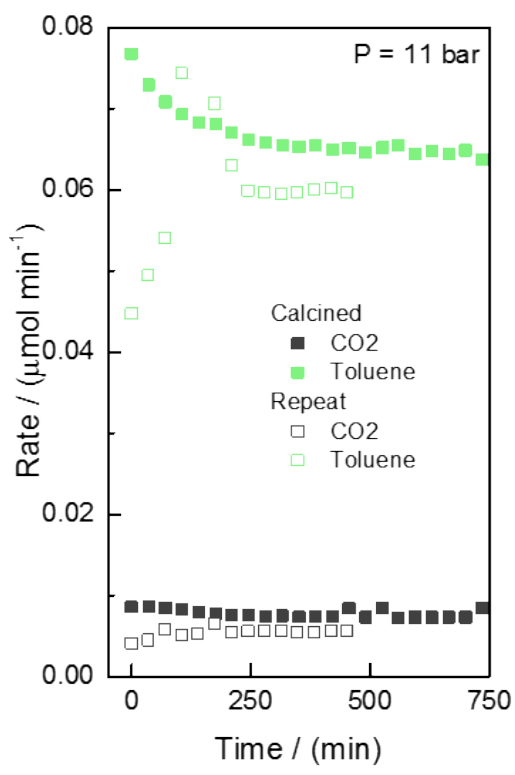

Figure S5. Rates of product formation over Cu-SSZ-13/H-ZSM-5 versus time-on-stream, demonstrating stable rates are observed for at least 12 hours. $(0.0875 \mathrm{~g} \mathrm{Cu}-\mathrm{SSZ}-13-1+$ $\left.0.2625 \mathrm{~g} \mathrm{H}_{-Z S M}-5-2\right), 543 \mathrm{~K}, 26.1 \mathrm{sccm}, \mathrm{y}_{\mathrm{CH} 4}=0.18, \mathrm{y}_{\mathrm{C} 6 \mathrm{H} 6}=0.008, \mathrm{y}_{\mathrm{O} 2}=0.001, \mathrm{P}_{\mathrm{H} 2 \mathrm{O}}=$ $3.1 \mathrm{kPa}$, bal He. Catalysts were calcined at $823 \mathrm{~K}$ under dry air for $8 \mathrm{~h}$ prior to testing. Repeat denotes the observed rates of product formation upon a second calcination of the same catalyst bed.

Table S3. Estimated $\mathrm{CH}_{4}$ conversion over Cu-SSZ-13 and Cu-SSZ-13/H-ZSM-5 with the alkylation feed mixture assuming all products were from $\mathrm{CH}_{4}$. Catalyst conditions: $0.0875 \mathrm{~g} \mathrm{Cu}-S S Z-13-1$, and (0.0875 g Cu-SSZ-13-1 + 0.2625 g H-ZSM-5-2), $26.1 \mathrm{sccm}$, $\mathrm{y}_{\mathrm{CH} 4}=0.18, \mathrm{y}_{\mathrm{C} 6 \mathrm{H} 6}=0.008, \mathrm{y}_{\mathrm{O} 2}=0.001, \mathrm{P}_{\mathrm{H} 2 \mathrm{O}}=3.1 \mathrm{kPa}$, bal He where $\mathrm{y}$ indicates mole fraction.

\begin{tabular}{|c|c|c|c|}
\hline \multirow[b]{2}{*}{$\begin{array}{c}\text { Temperature } \\
\text { (K) }\end{array}$} & \multirow[b]{2}{*}{$\begin{array}{l}\text { Pressure } \\
\text { (bar) }\end{array}$} & \multicolumn{2}{|c|}{$\mathrm{CH}_{4}$ Conversion (\%) } \\
\hline & & Cu-SSZ-13 & $\begin{array}{c}\text { Cu-SSZ- } \\
\text { 13/H-ZSM- } \\
5\end{array}$ \\
\hline 543 & 1 & 0.003 & 0.004 \\
\hline 543 & 11 & 0.02 & 0.035 \\
\hline 573 & 1 & 0.009 & 0.012 \\
\hline 603 & 1 & 0.02 & 0.03 \\
\hline 633 & 1 & 0.04 & 0.07 \\
\hline 663 & 1 & 0.08 & 0.13 \\
\hline
\end{tabular}




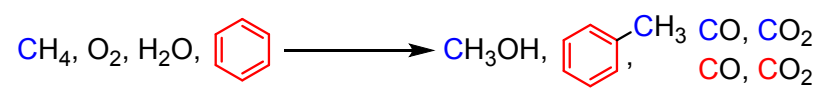

A

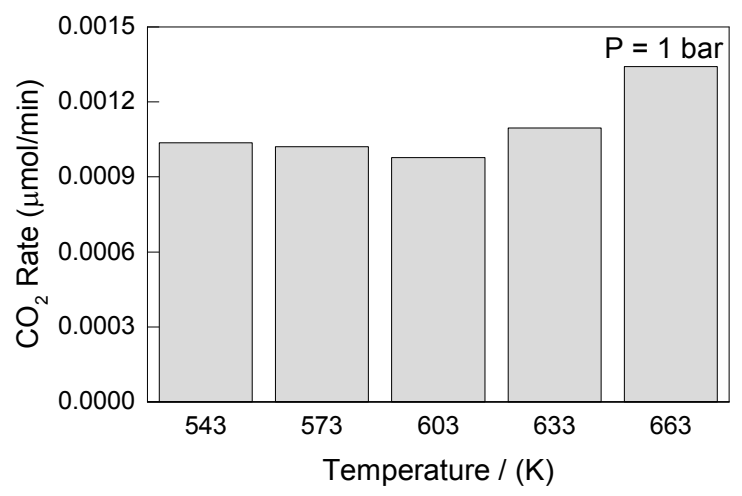

B

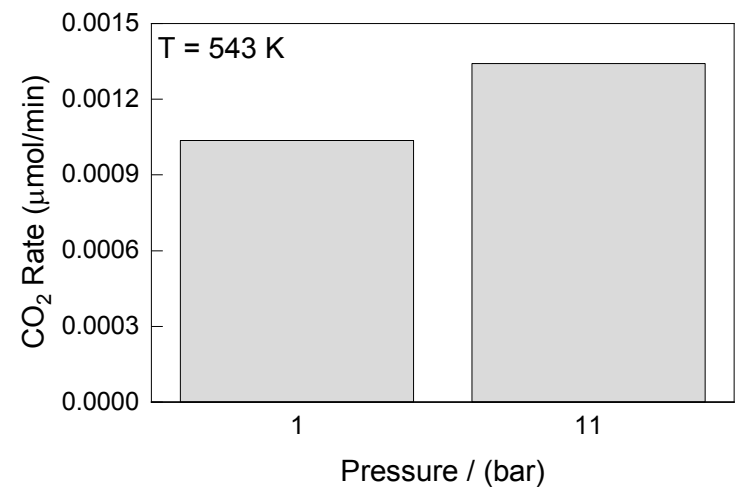

Figure S6. Rates of $\mathrm{CO}_{2}$ formation in the absence of catalyst across A. Pressure at 543 $\mathrm{K}, \mathrm{B}$. Temperature at 1 bar. $\mathrm{CO}_{2}$ was the only observed product. Flow conditions: 26.1 $\mathrm{sccm}, \mathrm{y}_{\mathrm{CH} 4}=0.18, \mathrm{y}_{\mathrm{C} 6 \mathrm{H} 6}=0.008, \mathrm{y}_{\mathrm{O} 2}=0.001, \mathrm{P}_{\mathrm{H} 2 \mathrm{O}}=3.1 \mathrm{kPa}$, bal He where $\mathrm{y}$ indicates mole fraction. When pressurizing, water partial pressure remains unchanged because water is introduced by a saturator, all other reactants increased proportionally.

\section{A. ${ }^{13} \mathrm{C}_{6} \mathrm{H}_{6}$ Isotope Switching Experiment}

To quantify the contribution of benzene oxidation to the observed rates of $\mathrm{CO}$ and $\mathrm{CO}_{2}$ formation, ${ }^{13} \mathrm{C}_{6} \mathrm{H}_{6}$ (Sigma Aldrich, 423637, 99 atom\%) isotope switching experiment was completed. Prior to the experiment, the catalyst bed was calcined under $50 \mathrm{sccm}$ dry air at $823 \mathrm{~K}$ for $8 \mathrm{~h}$ before cooling to $543 \mathrm{~K}$. At $543 \mathrm{~K}$ and 1 bar, reactant flows were introduced with unlabeled benzene until steady-state was attained. Steady state was tracked by GC and an online mass spectrometer (Hiden Analytical HPR-20/QIC). CO (m/z $=28),{ }^{13} \mathrm{CO}(\mathrm{m} / \mathrm{z}=29), \mathrm{CO}_{2}(\mathrm{~m} / \mathrm{z}=44),{ }^{13} \mathrm{CO}_{2}(\mathrm{~m} / \mathrm{z}=45)$, benzene $(\mathrm{m} / \mathrm{z}=78)$, and ${ }^{13} \mathrm{C}_{6}$ benzene $(\mathrm{m} / \mathrm{z}=84)$ were tracked by MS. Upon reaching steady-state, the benzene feed was switched to ${ }^{13} \mathrm{C}_{6} \mathrm{H}_{6}$ until a steady-state was reached. The feed was then switched back to unlabeled benzene. The catalyst bed was then heated to $603 \mathrm{~K}$ and the same experiment was repeated. The rates of $\mathrm{CO}$ and $\mathrm{CO}_{2}$ formation was unchanged with the change in benzene isotope. The change in MS signal of each species was assumed to respond linearly to the gas phase concentration of each species. The natural abundance of ${ }^{13} \mathrm{CO}$ and ${ }^{13} \mathrm{CO}_{2}$ were accounted for in accounting for the contribution of benzene oxidation to the rates of $\mathrm{CO}$ and $\mathrm{CO}_{2}$ formation as follows:

Prior to isotope switch:

$$
\begin{gathered}
\qquad \begin{array}{c}
x=\frac{{ }^{12} \text { CO signal }}{{ }^{13} \text { CO Signal }} \\
\text { Rate of }{ }^{13} \text { CO formation pre }- \text { switch }=\frac{\text { Total Rate of CO Formation }}{1+x}
\end{array}
\end{gathered}
$$


Following isotope switch:

$$
\begin{gathered}
\qquad \begin{array}{c}
{ }^{12} \text { CO signal } \\
{ }^{13} \text { CO Signal }
\end{array} \\
\text { Rate of }{ }^{13} \text { CO formation post }- \text { switch }=\frac{\text { Total Rate of CO Formation }}{1+y}
\end{gathered}
$$

Rate of CO formation from benzene $=$ Rate of ${ }^{13} \mathrm{CO}$ formation post - switch - Rate of ${ }^{13}$ CO formation pre - switch

$$
\text { Fractional Contribution of Benzene }=\frac{\text { Rate of } \mathrm{CO} \text { formation from benzene }}{\text { Rate of }{ }^{12} \mathrm{CO} \text { formation pre }- \text { switch }}
$$

Table S4 summarizes the contributions of benzene oxidation to the rates of $\mathrm{CO}$ and $\mathrm{CO}_{2}$ formation and Figures S8 and S9 present the MS signals. Due to the possible contribution of unlabeled and labeled benzene to $\mathrm{m} / \mathrm{z}=28$ and 29 and the large excess of benzene relative to $\mathrm{CO}$ formation, the contribution of benzene oxidation to $\mathrm{CO}$ formation could not be directly quantified and this analysis was omitted. We hypothesize contributions of benzene oxidation to $\mathrm{CO}$ formation rates are similar to benzene's contributions to $\mathrm{CO}_{2}$ formation rates.

Table S4. Percent contributions of $\mathrm{CH}_{4}$ and $\mathrm{C}_{6} \mathrm{H}_{6}$ to observed $\mathrm{CO}_{2}$ rate of formation at 543 and $603 \mathrm{~K}$ under tandem oxidation and alkylation reactions. (0.366 g Cu-SSZ-13-2 + $1.097 \mathrm{~g} \mathrm{H}-\mathrm{ZSM}-5-3$ ), Flow conditions: $78.3 \mathrm{sccm}, \mathrm{P}_{\mathrm{CH} 4}=17.8 \mathrm{kPa}, \mathrm{P}_{\mathrm{C} 6 \mathrm{H} 6}=0.80 \mathrm{kPa}, \mathrm{P}_{\mathrm{O} 2}$ $=0.09 \mathrm{kPa}, \mathrm{P}_{\mathrm{H} 2 \mathrm{O}}=3.1 \mathrm{kPa}$, bal He, atmospheric pressure.

\begin{tabular}{ccc}
\hline Temperature (K) & Source & $\mathrm{CO}_{2}$ \\
\hline \multirow{2}{*}{543} & $\mathrm{CH}_{4}$ & $81 \%$ \\
& $\mathrm{C}_{6} \mathrm{H}_{6}$ & $19 \%$ \\
\hline \multirow{2}{*}{603} & $\mathrm{CH}_{4}$ & $58 \%$ \\
& $\mathrm{C}_{6} \mathrm{H}_{6}$ & $42 \%$ \\
\hline
\end{tabular}



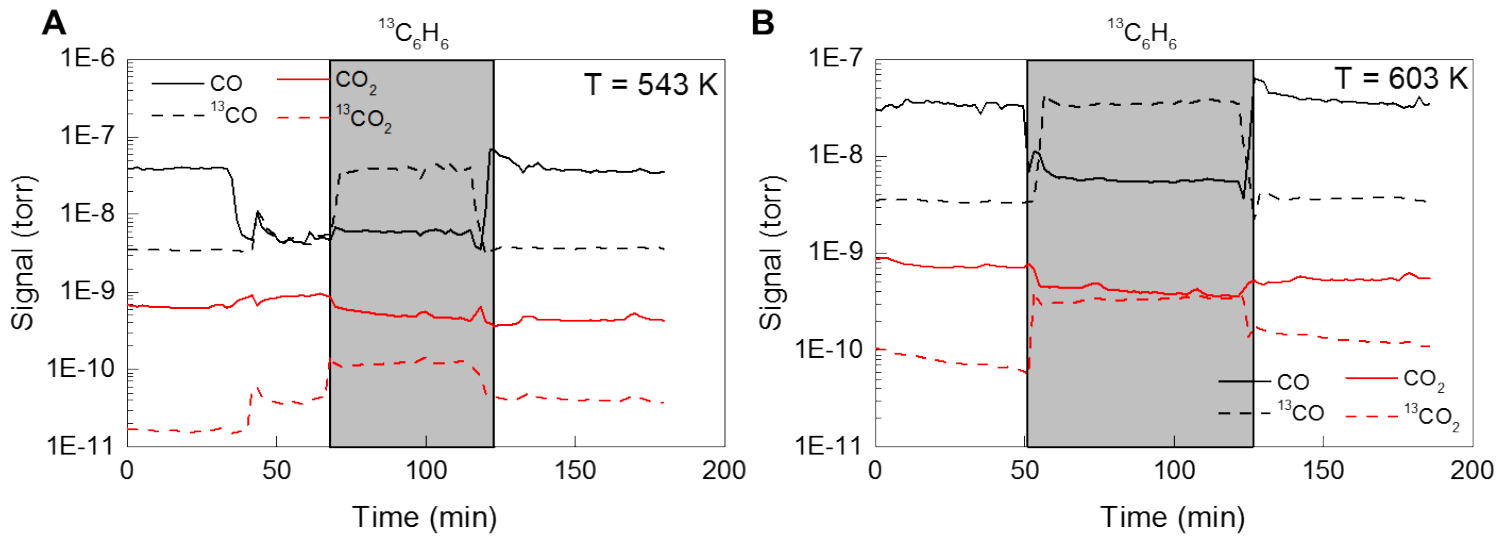

Figure S7. $\mathrm{CO}$ and ${ }^{13} \mathrm{CO}$ and $\mathrm{CO}_{2}$ and ${ }^{13} \mathrm{CO}_{2}$ signals under tandem oxidation and alkylation conditions and upon the introduction of ${ }^{13} \mathrm{C}_{6}$ benzene (gray box) at $\mathrm{A} .543 \mathrm{~K}$ and B. $603 \mathrm{~K}$. (0.366 g Cu-SSZ-13-2 + $1.097 \mathrm{~g} \mathrm{H}-Z S M-5-3)$, Flow conditions: $78.3 \mathrm{sccm}$, $\mathrm{P}_{\mathrm{CH} 4}=17.8 \mathrm{kPa}, \mathrm{P}_{\mathrm{C} 6 \mathrm{H} 6}=0.80 \mathrm{kPa}, \mathrm{P}_{\mathrm{O} 2}=0.09 \mathrm{kPa}, \mathrm{P}_{\mathrm{H} 2 \mathrm{O}}=3.1 \mathrm{kPa}$, bal He, atmospheric pressure. In Figure $A$, between $\sim 40-70$ min, there was a leak of ${ }^{13} \mathrm{C}_{6}$ benzene and, thus, benzene was not taken into the gas stream during this time.

A

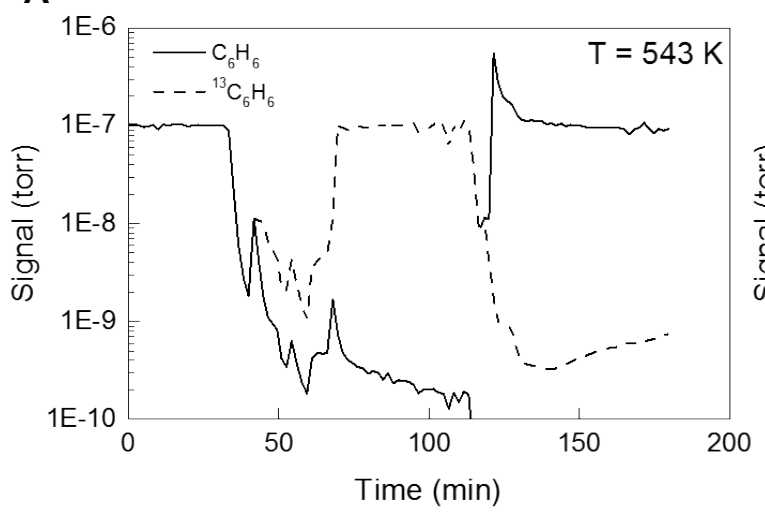

B

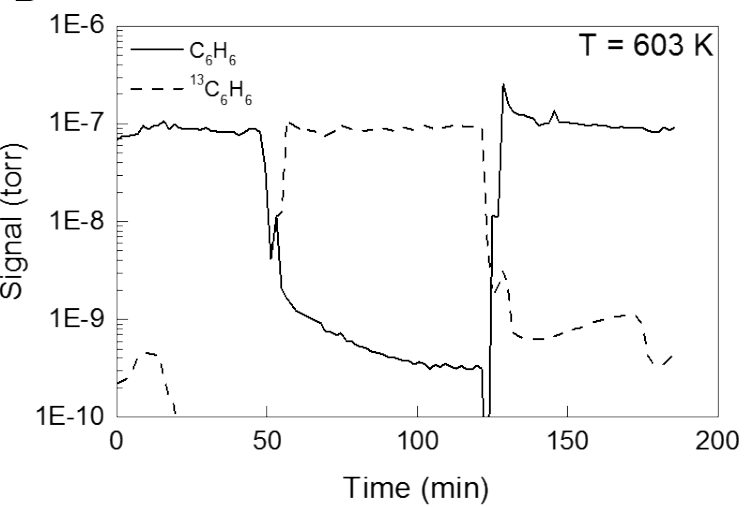

Figure S8. Benzene and ${ }^{13} \mathrm{C}_{6} \mathrm{H}_{6}$ signals under tandem oxidation and alkylation conditions and upon the introduction of ${ }^{13} \mathrm{C}_{6}$ benzene at A. $543 \mathrm{~K}$ and B. $603 \mathrm{~K} .(0.366 \mathrm{~g} \mathrm{Cu}-\mathrm{SSZ}-$ $13-2+1.097 \mathrm{~g} \mathrm{H}-\mathrm{ZSM}-5-3$ ), Flow conditions: $78.3 \mathrm{sccm}, \mathrm{P}_{\mathrm{CH} 4}=17.8 \mathrm{kPa}, \mathrm{P}_{\mathrm{C} 6 \mathrm{H} 6}=0.80$ $\mathrm{kPa}, \mathrm{P}_{\mathrm{O} 2}=0.09 \mathrm{kPa}, \mathrm{P}_{\mathrm{H} 2 \mathrm{O}}=3.1 \mathrm{kPa}$, bal $\mathrm{He}$, atmospheric pressure. In Figure $\mathrm{A}$, between $\sim 40-70 \mathrm{~min}$, there was a leak of ${ }^{13} \mathrm{C}_{6}$ benzene and, thus, benzene was not taken into the gas stream during this time. 


\section{B. Estimation of Benzene Oxidation Across Conditions}

Based on the observed rate of $\mathrm{CO}_{2}$ formation stemming from benzene at 543 and $603 \mathrm{~K}$, 1 bar, estimates of the contribution of benzene oxidation to $\mathrm{CO}_{2}$ formation rates were obtained by using kinetic dependences and estimates of apparent activation energies. An estimate of the apparent activation energy for $\mathrm{CO}_{2}$ formation from benzene was obtained from Figure 2B. The apparent activation energy for $\mathrm{CO}_{2}$ was $79 \mathrm{~kJ} / \mathrm{mol}$. Figure 3D demonstrates the rate of $\mathrm{CO}_{2}$ formation is independent of $\mathrm{P}_{\text {benzene }}$ and Figure S9 demonstrates the dependence of $\mathrm{CO}_{2}$ formation from benzene on $\mathrm{P}_{\mathrm{O} 2}$ is 0.4 order. These results allow for estimation of the contribution of benzene oxidation to $\mathrm{CO}_{2}$ formation rates across temperature and pressure.

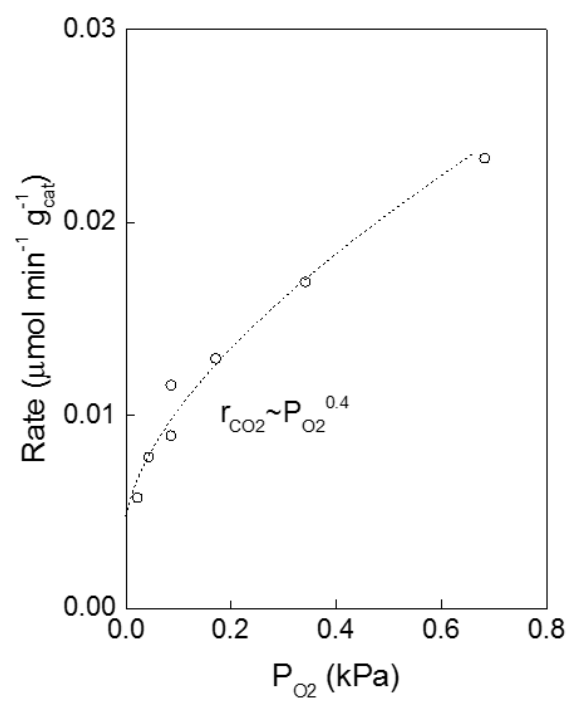

Figure S9. Product formation rate dependence on $\mathrm{P}_{\mathrm{O} 2}$ for benzene oxidation in the absence of $\mathrm{CH}_{4}$. $\mathrm{CO}_{2}$ was the only observed product. $(0.2625 \mathrm{~g} \mathrm{Cu}-\mathrm{SSZ}-13-1+0.7875 \mathrm{~g}$ $\mathrm{H}-\mathrm{ZSM}-5-1), 74.5 \mathrm{sccm}, 543 \mathrm{~K}, \mathrm{P}_{\mathrm{O} 2}=0.1 \mathrm{kPa}, \mathrm{P}_{\text {benzene }}=0.80 \mathrm{kPa}, \mathrm{P}_{\mathrm{H} 2 \mathrm{O}}=3.1 \mathrm{kPa}$, bal $\mathrm{He}$. 

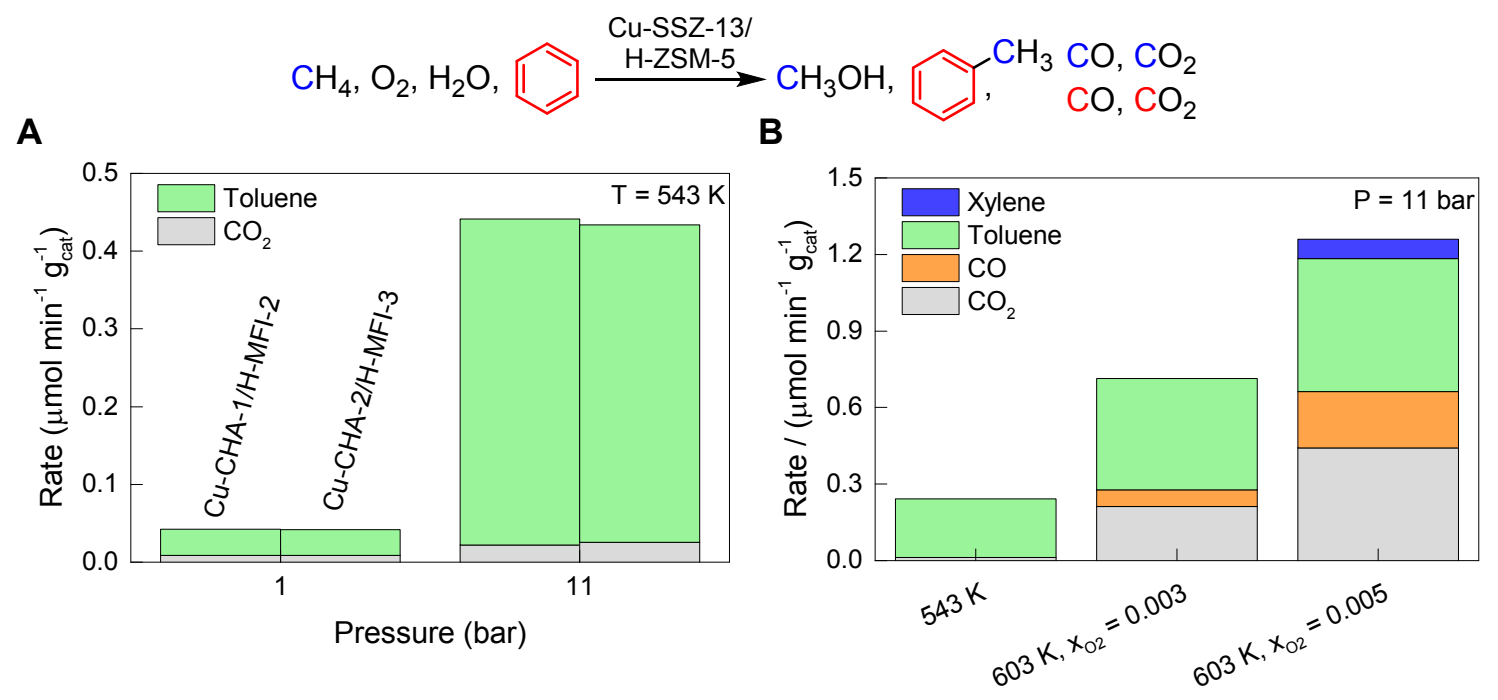

Figure S10. Rates of product formation over Cu-SSZ-13-2/H-ZSM-5-3 for tandem oxidation and alkylation across conditions. A. Comparison of Cu-SSZ-13-1/ H-ZSM-5-2 and Cu-SSZ-13-2/ H-ZSM-5-3 demonstrating same rates are observed at SV $=329 \mathrm{~g}_{\mathrm{cat}}$ $\left(\mathrm{mol} \mathrm{min}^{-1}\right)^{-1}$ B. Product formation rates across multiple conditions over Cu-SSZ-13-2/ HZSM-5-3. $1372 \mathrm{~g}_{\text {cat }}\left(\mathrm{mol} \mathrm{min}^{-1}\right)^{-1}$. (0.0875 g Cu-SSZ-13-1 + 0.2625 g H-ZSM-5-2), (0.366 g Cu-SSZ-13-2 + $1.097 \mathrm{~g} \mathrm{H}-\mathrm{ZSM}-5-3$ ), $\mathrm{y}_{\mathrm{CH} 4}=0.18, \mathrm{y}_{\mathrm{C} 6 \mathrm{H} 6}=0.008, \mathrm{y}_{\mathrm{O} 2}=0.001$ (unless otherwise noted), $\mathrm{P}_{\mathrm{H} 2 \mathrm{O}}=3.1 \mathrm{kPa}$, bal He. When pressurizing, water partial pressure remains unchanged, all other reactants increased proportionally. 
Table S5. Observed $\mathrm{CH}_{4}$ conversion, selectivity and product yield for tandem oxidation and alkylation over Cu-SSZ-13/H-ZSM-5 ${ }^{\text {a }}$

\begin{tabular}{|c|c|c|c|c|c|c|}
\hline Catalyst & $\begin{array}{l}\text { Temperature } \\
(\mathrm{K})\end{array}$ & $\begin{array}{l}\text { Pressure } \\
\text { (bar) }\end{array}$ & $\begin{array}{l}\text { Space } \\
\text { Velocity } \\
\left(g_{\text {cat }}(\mathrm{mol}\right. \\
\left.\left.\min ^{-1}\right)^{-1}\right)\end{array}$ & $\begin{array}{c}\mathrm{CH}_{4} \\
\text { Conversion } \\
(\%)\end{array}$ & $\begin{array}{c}\text { Toluene + } \\
\text { Xylene } \\
\text { Selectivity } \\
(\%)\end{array}$ & $\begin{array}{l}\text { Product } \\
\text { Yield } \\
\left(\mu \mathrm{mol}^{\mathrm{d}}\right. \\
\mathrm{min}^{-1} \\
\mathrm{~g}_{\text {Cu-ssz- }} \\
\left.13^{-1}\right)\end{array}$ \\
\hline \multirow{11}{*}{$\begin{array}{c}\text { Cu- } \\
\text { SSZ-13- } \\
1 / \\
\text { H-ZSM- } \\
5-2\end{array}$} & 543 & 1 & 329 & 0.004 & 70 & 0.06 \\
\hline & 573 & 1 & 329 & 0.009 & 100 & 0.19 \\
\hline & 603 & 1 & 329 & 0.023 & 98 & 0.48 \\
\hline & 633 & 1 & 329 & 0.054 & 85 & 0.98 \\
\hline & 663 & 1 & 329 & 0.099 & 77 & 1.64 \\
\hline & 543 & 11 & 329 & 0.039 & 89 & 0.68 \\
\hline & 543 & 11 & 329 & 0.022 & 89 & 1.13 \\
\hline & 543 & 1 & 329 & 0.004 & 77 & 0.06 \\
\hline & 543 & 1 & 163 & 0.003 & 72 & 0.08 \\
\hline & 543 & 1 & 81 & 0.002 & 64 & 0.09 \\
\hline & 543 & 1 & 41 & 0.001 & 51 & 0.11 \\
\hline \multirow{5}{*}{$\begin{array}{c}\text { Cu- } \\
\text { SSZ-13- } \\
2 / \\
\text { H-ZSM- } \\
5-3 \\
\end{array}$} & 543 & 1 & 329 & 0.003 & 69 & 0.06 \\
\hline & 543 & 11 & 329 & 0.034 & 88 & 0.72 \\
\hline & 543 & 11 & 1372 & 0.085 & 97 & 0.91 \\
\hline & $603^{b}$ & 11 & 1372 & 0.37 & 80 & 1.74 \\
\hline & $603^{c}$ & 11 & 1372 & 0.66 & 59 & 2.70 \\
\hline
\end{tabular}

Reactant feed composition: $\mathrm{y}_{\mathrm{CH} 4}=0.18, \mathrm{y}_{\mathrm{C} 6 \mathrm{H} 6}=0.008, \mathrm{y}_{\mathrm{O} 2}=0.001, \mathrm{P}_{\mathrm{H} 2 \mathrm{O}}=3.1 \mathrm{kPa}$, bal $\mathrm{He}$

${ }^{b} \mathrm{x}_{\mathrm{O} 2}=0.003$

${ }^{c} \mathrm{X}_{\mathrm{O} 2}=0.005$

dSelectivity and product yield are C-weighted based on number of moles of $\mathrm{CH}_{4}$ incorporated. (e.g., $1 \mathrm{C} /$ Toluene and $2 \mathrm{C} /$ Xylene); xylene was only observed for the last table entry. Selectivities are calculated upon accounting for contribution of benzene oxidation to observed $\mathrm{CO}_{2}$ rate of formation. 


\section{References}

1. Baerlocher, C.; McCusker, L. B., Database of Zeolite Structures. 2016 ed.; International Zeolite Association.

2. GradientCheck for Heterogeneous Catalysis, 0.95; Purdue Catalysis Center and Dow Chemical Company: West Lafayette, Indiana, 2016.

3. $\quad$ NIST Chemistry WebBook: NIST Standard Reference Database Number 69. U.S. Department of Commerce National Institute of Standards and Technology: Washington, D.C., 2018. 